\title{
Non-Classical Approach to a History of Philosophy: Modern Status and Research Prospects
}

\author{
Vadym Tytarenko \\ Ph.D., Associate Professor, Taras Shevchenko National University of Kyiv \\ (Kyiv, Ukraine) \\ E-mail: tytarenko.vadym@gmail.com \\ https://orcid.org/0000-0001-9251-8859
}

\begin{abstract}
The paper touches upon some issues on the present condition and prospects of the research methodology in the field of history of philosophy. The author claims that modern Ukrainian history of philosophy is mostly grounded on the principles of a classical theoretical approach which date back to the philosophical traditions of Hegelianism and Marxism. The classical approach is determined by a specific theory of the hitorico-philosophical process in which it appears as a particular linear set of events objectively connected and influencing each other. Such theory presupposes a certain set of methods and rules of their application. This peculiarity makes the system isolated from the others and provides limitations that influence the effectiveness of the research.

The author asserts that to optimize the effectiveness and increase the heuristic potential of the research in the field of history of philosophy the classical methodological approach should be gradually replaced by the non-classical. The main properties of the non-classical approach are openness, methodological communication with the other research fields, equal evaluation of the importance of various philosophical notions, personalities and events. Author, generalizing the modern research experience in the field of methodology of history of philosophy, suggests several strategies for improvement and transformation of the existing research methodology and the development of a non-classical approach to the history of philosophy.
\end{abstract}

Keywords: history of philosophy, methodology, method, theory, Ukrainian philosophy, Hegel, Marx

Received: August 19, 2019; accepted: September 16, 2019

Future Human Image, Volume 12, 2019: 121-128.

https://doi.org/10.29202/fhi/12/11

\section{Introduction}

The modern science of history of philosophy still operates with the classical theory and research methodology developed in the $19^{\text {th }}$ century by Georg Wilhelm Friedrich Hegel. This methodology remains deeply implemented into the strategy of conducting philosophical research and into the system of education in the field of arts and humanities and social science. However, in the Ukrainian research practice in the field of history of philosophy, the most

(C) Tytarenko, Vadym, 2019 
components of the classical theory of the development of the history of philosophy remain inapplicable and problematic, i.e. they are not suitable for the analysis of the most of the texts. Moreover, Hegel's theory of the history of philosophy demonstrates the inefficiency and uncompetitiveness in contemporary educational practice. At the same time, in the modern historico-philosophical literature there is no essential alternative to the classical historico-philosophical theory. At the moment, there are many studies aimed at the theoretical and methodological transformation of the science of history of philosophy following the demands and needs of the modern information society. Unfortunately, all such researches remain non-generalised and, consequently, inapplicable to the specific research practice in the field of history of philosophy. Our research presented in this paper hypothesizes that the classical theory of the historical development of philosophy is exhausted and should be replaced by theoretical principles and methodological tools relevant to the needs and demands of modern society. In other words, the modern science of history of philosophy requires a new theoretical and methodological approach, which, in our opinion, can be defined as "non-classical approach to the history of philosophy. " Development of this direction can be realized through the combination of two basic approaches: a) generalization and systematization of the available historico-philosophical researches focused on critical reconsideration of Hegel's concept of the history of philosophy; b) development and introduction of new theoretical principles of the historical development of philosophy. According to our hypothesis, the modern demands of the historico-philosophical science are connected with the exclusion of the principles of consistency, sublation, continuity, the formation of a single model of the historical development of a philosophy based on the certain principles, etc. That is why one of the prospects for the development of non-classical historical and philosophical theory is to involve the advancements of analytical tradition, structuralist and poststructuralist studies, modern philosophy of science, etc.

\section{Modern theories of historico-philosophical process. Benefits, drawbacks and prospects}

The science of history of philosophy is generally focused on the "historico-philosophical process." By using this term we mean the multi-dimensional historical development of philosophy (personalities, concepts, ideas, theories etc.) The adjective "historico-philosophical" is not commonly used in Anglo-American literature. After a brief inquiry into the cases of its use, the authors concluded that there would be no misinterpretation. For instance, Professor Charles T. Wolfe uses this term in the title of his book on the brief history of materialism [Wolfe, 2015]. Moreover, in case of Ukraine and other post-Soviet countries this term perfectly fits the way of a typical description of any issue related to the history of philosophy such as process, theory, methodology, etc. and widely used by the scholars.

Today, there are many theories of the historico-philosophical process, which can be divided into two main groups: those that consider the history of philosophy as a consolidated and unified process of progressive development of philosophical ideas (Hegel's and Marx's theories of the historico-philosophical process) and those that suggest that the history of philosophy should be understood as a set of philosophical ideas that do not have a clear line of development, but which emerge and interact chaotically.

Most of the historians of philosophy from Ukraine and other post-Soviet countries prefer the former group of theories to the later. Such attitude could be explained by the claim that the first group of theories is more profound, scientific and rational, while the second group, which 
is not based on the systematic rational scientific methodology appears to be irrational and as a result not suitable for a true scientific application. A striking example of such preference could be found in the book "Methodology of historico-philosophical research" [Kamenski, 2002] composed by one of the most authoritative Russian-Ukrainian ${ }^{1}$ historians of philosophy an expert in scientific methodology Zahar Kamenskii. He writes the following lines.

"Opponents who oppose the necessity for developing of such a methodology (rational scientific methodology of history of philosophy - author's remark) assert, however, that even if we set ourselves a predetermined goal (which, in their opinion, is not necessary, since the historico-philosophical research can be presented in some free narrative form, in the form of an essay), it can be achieved by various, not pre-programmed means, driven by the research situation, the logic of the subject of the research, scientific intuition or other circumstances. Dilettantism and sophistry are mixed in such a view. Its proponents deny the scientific character of the history of philosophy, whose (scientific character) consists, among other things, in the fact that the history of philosophy intends to reproduce the common in the various individual subjects of its investigation. For this purpose, it seeks, based on general definitions of the characteristics of the moments of its diverse subject, the means which are identical for similar research tasks and situations... Historico-philosophical research (or reconstruction), which is conducted with no understanding of goals and methodology, based on spontaneous solving of research tasks, is irrational" ${ }^{2}$ [Kamenski, 2002: 75, 77].

Similar attitude could be found in the theoretical and methodological papers of other Ukrainian and Russian scholars of the Soviet period (Pavlo Kopnin, Volodymyr Shynkaruk, Teodor Oizerman, Mykhailo Bulatov, Yourii Kushakov and others). In their consideration, the historical investigations in the field of philosophy must be conducted on the basis of rational and well-defined methodology. More detailed information on the contribution of the aforementioned historians of philosophy could be found in the recent article by Sergii Rudenko. [Rudenko \& Tytarenko, 2018]

Such a tendency to magnify the linear and rational models of the history of philosophy is not only typical for post-Soviet research traditions. The similar recommendations were given by some American philosophers. It is a well-known fact that there were two well organised and productive philosophical schools in the USA in the late 19th century inspired and influenced by the philosophy of Hegel. They were Ohio Hegelians (John Stallo, Peter Kaufmann, Moncure Conway, August Willich) [Easton, 1962: 355] and St. Louis Hegelians (William Torrey Harris, Henry Conrad Brokmeyer, Josiah Royce, William McKendree Bryant, Thomas Davidson) [DeArmey \& Good, 2001]. The recent investigations [Sobolievskyi, 2018] on these two philosophical groups reveal their adherence to Hegel's theory on the linear development of human history as well as to his methodology of history of philosophy.

Another example of such adherence is the way how the history of Philosophy is currently taught in some American colleges. To some extent, the different personalities are presented as not equally sufficient but subordinate. Professor Lawrence Cahoon from the College of the

\footnotetext{
${ }^{1}$ Zahar Kamenski was born in Luhansk — the city in eastern Ukraine, but almost all his life he lived and worked in Moscow.

${ }^{2}$ The original text of this book was published in Russian three years after Zahar Kamenski's death. The English translation of the quoted fragments was done by the author of the article.
} 
Holy Cross (USA) in his recent course "The Modern Intellectual Tradition — From Descartes to Derrida" (Lecture 10 "The French Revolution and German Idealism") claims that "Kant... is the precorse of the German idealism or its beginning. Hegel is its complete fulfilment. Fichte and Shelling are transitional figures, great philosophers on their own... but between Kant and Hegel" [Cahoon, 2010: 30-31].

The modern Ukrainian tradition of teaching the history of philosophy mostly follows the aforementioned strategy. The historico-philosophical curricula of most Ukrainian universities are composed using the typical Hegelian and Marxist schemes of understanding of the general line and peculiarities of the development of philosophy. Such an evaluation could be found in numerous research papers written by contemporary Ukrainian scholars. Let us observe some most representative. Taras Kononenko the head of the Department of History of Philosophy at the Taras Shevchenko National University of Kyiv writes the following lines on this issue.

"Philosophy education in the field of humanities is not a random selection of activities, but an ordered sequence of operations, which is finally culminating in the obtaining of a diploma of full philosophical education... In particular, the research interest should have been directed to such a significant component of philosophical education as "history of philosophy" and its role in the education process. The issue of renewing the teaching of the history of philosophy in Ukraine has a long history and lasts for more than two decades. However, all previous attempts have faced difficult theoretical circumstances related to the systemic peculiarities of construction of the Hegelian model of organizing the historico-philosophical material. Nowadays, the "matrix" of the history of philosophy composed by Georg Wilhelm Friedrich Hegel strongly determines the principles of teaching the history of philosophy in Ukrainian universities. We have a sad circumstance, which could be expressed by the following statement: "Hegelian immanentism cannot be overcome in an immanent way. That is, within the established order of studying history of philosophy, it is impossible to update the foundations of historical and philosophical education by means that determine this order"3 [Kononenko, 2017: 32].

Akin claims but which mostly concern the methodology of historical investigations of the national, local philosophical though were proposed by Sergii Rudenko in his recent monograph "Modern methodological conceptions of inquiry of History of Ukrainian philosophy" [Rudenko, 2012]. For the last decade, more and more scholars insist on the necessity of reconsideration of the widespread but outdated Hegel's and Marx's theories of historico-philosophical process.

The second group of the theories based on the idea that the methodology of arts and humanities cannot be similar to the methodology of natural science. This idea dates back to the late 19th century and was propounded by the representatives of neo-Kantianism (Baden School). This idea was later profoundly developed by Wilhelm Dilthey in his book "Einleitung in die Geisteswissenschaften" (Introduction to the Human Sciences). The approach of the natural sciences is focused mainly on the generalisation of their objects whereas the humanities (human sciences) aim to represent their objects with all possible individualisation. The systematic approach reveals its major limitation when one attempts to use it for the ultimate explanation of any phenomenon of human existence. This happens because life appears to be

${ }^{3}$ The original text of this book was published in Ukrainian. The English translation of the quoted fragments was done by the author of the article. 
always wider and deeper than any rational that we would try to use for its description and understanding. History of philosophy in the from the perspective of such an approach is a set of events that should be profoundly described to comprehend their individuality. Any systematic representation of these events claimed to be limited and of relative heuristic potential.

Authors of the article claim that both theoretical representations of the development of philosophy (theories of the historico-philosophical process) have their advantages and drawbacks. The non-classical approach to the history of philosophy should preserve the benefits of both and try to get rid of the disadvantages. As many evaluation criteria and methods as possible should be used to avoid one-sidedness in the study of this complex subject. The truth is always in the middle between the extremes.

\section{The methodology of the history of philosophy. Prospects for non-classical approach}

Along with the theory of the historico-philosophical process, an important place in the structure of historico-philosophical science is taken by the methodology that determines the way and character of the conducted research. These two parts of the history of philosophy justify each other. The methodology of historico-philosophical science depends on the theory of the historico-philosophical process because in the most general sense the methods appear to be the methodological specification of the theory. Conversely, the development of methodology directly affects the way and character of further development of theoretical comprehension of the historico-philosophical process.

In the most general sense, the classical approach to the history of philosophy presupposes the usage of general scientific methods, adapting and transforming them following the specifics of the subject of the research. History of philosophy is closely linked to other related research disciplines, borrowing certain proven methodological techniques from them. But at the same time, the history of philosophy, being an independent scientific discipline, has a set of special methods, operations and procedures implemented only within its framework.

The essential requirement of the classical approach to the history of philosophy, widespread in most post-Soviet countries, is that its methodology must be normative, generalizing and unified. Such requirement provides the connection of the historico-philosophical methodology with the general methodology of science. The necessity of such connection was for the first time stressed by Francis Bacon and Rene Descartes who are regarded as the founders of the tradition of modern science. Such representation means this there must be a hierarchic connection between groups of methods.

Aforementioned Zahar Kamenski in the previously quoted book gives the following generalized image of the common scientific methodology and its particularization in the science of history of philosophy.

"There are many classifications of scientific methods based on different principles, but the most common is that they are divided into philosophical, general-scientific and special-scientific methods; the general-scientific methods are usually considered to be those that, once created in a particular field of science, are applicable in other sciences as well: these are systemic, cybernetic, structuralist methods, etc. General scientific methods also include methods distinguished according to other criteria: quantitative and qualitative, empirical and rational, clearly deterministic and probabilistic, etc... 
Since all the forms of historico-philosophical research have common traits due to this specificity, there are also common, universal methods, i.e. methods used in any form of historico-philosophical research. Thus, for each of the two generalizing forms of historico-philosophical research, both general and special methodology should be developed." [Kamenski, 2002: 72]

Another important requirement of the classical approach is that the methodology must be grounded in the particular "basic system". Basic system means the philosophical system that determines the general frames of interpretation of any arising issue. Most important elements of the basic system that should be taken into consideration are epistemology (which provides the general awareness of possible knowledge); the general worldview (which provides the understanding on how the elements of the reality connected). For a classical approach to the history of philosophy, the basic system must be rational, certain, non-sceptical in terms of the possibility of gaining knowledge. Striking examples of such basic systems are Hegelianism and Marxism. The basic system determines the aims and forms of the research as well as provides the rational limitation for the use of some particular methods. For instance, the methods allowed in one system might become non-applicable in the other.

In the case of Ukrainian history of philosophy, the methodology of the provided research is mostly classical. This is due to the commonly accepted classical (Marxist-Hegelian) understanding of the development of philosophical thought. At the same time, there is no single determined research strategy (in terms of research methods and procedures) that would be common for all scholars. The Ukrainian science of history of philosophy currently demonstrates the methodological eclectics. Some scholars emphasize the negative connotation of such a situation. Sergii Rudenko, supporting the general opinion on Ukrainian history of philosophy expressed by Yourii Kushakov", makes the following statement. "Moreover, the lack of generalization and systematization of the results of scientific research devoted to theoretical and methodological problems of research on the history of Ukrainian philosophy leads to a situation of "methodological confusion" typical for the Ukrainian historico-philosophical science" [Rudenko, 2013: 95].

In author's opinion, the efficiency of Ukrainian history of philosophy can only be increased by overcoming such "confusion" not only regarding the inquires which concern Ukrainian philosophy but regarding any inquiry in the field of history of philosophy. We claim that one of the possible solutions in this regard is the development of the new non-classical approach. Such an approach should be developed based on the reconsidered theory of historico-philosophical process and additional complex methodology of the research. Such an approach is a matter of future studies. Following some ideas of the aforementioned scholar Yourii Kushakov, we want to discuss some productive strategies for transformation and enrichment of the existing methodology.

The first perspective way of developing the methodology of historico-philosophical science is the methodological generalization of contemporary particular practical cases, which in its best examples contain rich, but mostly not reflected (in terms of methodology), material. The researcher should always look back to the most general principles of conducting historico-philosophical research to form the strategy of its particular application in certain research. In our opinion, the results of such productive individual methodological transformations should be accumulated by the history of philosophy for its product development. An

${ }^{4}$ See Kushakov, 2004: 91 
example of such an author-transformed methodological apparatus is the specific methodology of historico-philosophical research, developed and fruitfully applied in the multi-volume work "History of Ancient Aesthetics" by Russian scholar Aleksei Losev.

A second possible way of developing of historic-philosophical methodology, it a generalised consideration of methodological experience accumulated in related scientific disciplines, such as the history of science, history of literature, history of culture, etc. Productive involvement of the methodological achievements of related scientific disciplines can only be accumulated by the history of philosophy if they are transformed due to its standards and needs. In this way, it is possible to overcome the specific-subjective closeness of historico-philosophical science, as well as of all other branches of historico-scientific knowledge. Such an attitude is in line with the idea of future "methodological universalism".

The third promising area of enrichment of historico-philosophical methodology is the proper assessment of all historico-philosophical experience of the past, in order to avoid unnecessary work already done; and to overcome the traditional for Marxism idea that "the philosophical thought of modernity holds in a "sublated" form all the wealth of the history of the philosopher"s [Kushakov, 1989: 10]. Reconsideration of this "superiority" principle allows to asses all the stages of the development of philosophical thought as equally important. In the historico-philosophical research, the experience of the precursors, which we ought to regard as the contemporaries because of the invariability of the "big" philosophical questions, is highly important. "Philosophy deals first of all with "eternity" and with "eternal" problems of being and non-being. That is why all prominent thinkers of the past, who have been reflecting intensively on these questions, are not just sages, whose voices are heard from the depths of time, but our contemporaries" [Kushakov, 1989: 12]. The proposed strategies do not exhaust the list of possible measures. This list could be completed by other reasonable measures.

\section{Conclusions}

A classical scientific approach to a history of philosophy was mainly grounded on the linear, "closed", invariant interpretations of the development of the history of philosophy (historico-philosophical process) and related set of research methodologies. The main drawback of such theories can be seen, first of all, in their methodological isolation, in the lack of opportunities for cooperation with other points of view to expand the research field and increase the efficiency of research. Striking examples of such classical approaches to the history of philosophy are the historico-philosophical conceptions by Georg Wilhelm Friedrich Hegel and Karl Marx, which were not only methodologically closed and focused on the rational ideal of classical science but also convinced of the scientific superiority of their approaches.

The current development of science requires different approaches, both theoretical and methodological. Classical ideals of scientific rationality do not correspond to modern scientific demands and educational standards. However, science and education in the field of history of philosophy are still based on the principles of classical historico-philosophical theories. Although in other scientific fields these principles are no longer considered efficient and productive.,

In our opinion, the productivity of modern historico-philosophical researches can be increased through a gradual transition from classical to non-classical principles of understanding of the history of philosophy as well as its methodology (approaches, principles and methods).

${ }^{5}$ This way of evaluation of the historico-philosophical process was proposed and applied by G.W.F. Hegel in his studies, and then accepted by the Marxist paradigm of history of philosophy. 
One of the important principles of non-classical theory of history of philosophy is openness, which includes two aspects: a) readiness for a productive reception of methodological and theoretical solutions from related scientific fields, openness to modern demands and challenges, orientation towards innovation, rejection of dogmatism and strict traditionalism, methodological mobility; b) initial "presumption of equality" in processing of historico-philosophical materials which results in the recognition of any personality or doctrine of the history of philosophy as a self-sufficient unit, disregarding well-established "clichés", "considerations", "schemes", systems, etc. Openness in this sense reveals a fundamentally new approach to the historico-philosophical process in general (for instance, providing an opportunity to consider all philosophers of the past as contemporaries) and the methodology of historico-philosophical research in particular. The non-classical approach in the modern history of philosophy will intensify the general transformation and harmonization processes between scientific and educational traditions of Ukraine and the European Community, which corresponds to the general European integration policy of Ukraine.

\section{[D] References}

DeArmey, Michael H., Good, James A. The St Louis Hegelians. American Hegelianism, History of American Thought, Volume 2. A\&C Black, 2001. 840 p.

Cahoon, Lawrence. The Modern Intellectual Tradition — From Descartes to Derrida. The Great Courses. Chantilly, 2010. 137 p.

Easton, Loyd D. Hegelianism in Nineteenth-Century Ohio. Journal of the History of Ideas. Vol. 23, No. 3 (Jul. — Sep. 1962), pp. 355-378

Kamenski, Zahar. The methodology of historico-philosophical research. IFRAS, 2002, 371p.

Kononenko, Taras. The conception of the "Programme of the history of philosophy": idea conception - a conceptual model. The bulletin the Taras Shevchenko National University of Kyiv. Philosophy. Vol.1, 2017, pp. 32-34.

Kushakov, Yourii. Shestov: historian of philosophy or adept at "spiritual troublemaking"? Scientific notes of the Taras Shevchenko National University of Kyiv. Vol. 12. Faculty of Philosophy. Moscow: Pedagogy, 2004.

Kushakov, Yourii. On some promising ways of developing of historico-philosophical methodology. Problems of philosophy. Vol. 82, Kyiv 1989, pp.- 3-12.

Rudenko, Sergii. Modern methodological conceptions of inquiry of History of Ukrainian philosophy. Kyiv: Vydavnycho-polihrafichnyy tsentr "Kyyivs'kyy universytet", 2012.

Rudenko, Sergii. History of Ukrainian philosophy: non-descriptive research methodology. Philosophical Thought, 2013 № 5, pp. 94-102.

Rudenko, Sergii, and Vadym Tytarenko. Kant's Studies in Ukrainian Philosophy of Soviet Period. Future Human Image, Volume 9, 2018: 107-114. https:// doi.org/10.29202/ fhi/9/11

Sobolievskyi, Yaroslav. Soviet and Ukrainian Studies of American Philosophy: Translation of Philosophical Texts. Future Human Image, Vol. 9. Kyiv: ISPC, 2018. 100-106. https:// doi.org/10.29202/fhi/9/10

Wolfe, Charles T. Materialism. A Historico-Philosophical Introduction. Dordrecht: Springer Briefs, 2016, 134 p. 